\title{
Impact Analysis of Renewable Energy based Generation in West Africa - A case study of Nigeria
}

\section{Analiza produkcji opartej na odnawialnych źródłach energii w Afryce Zachodniej - studium przypadku Nigerii}

\section{Temitope M. Adeyemi-Kayode*, Sanjay Misra*, ${ }^{* *}$, Robertas Damaševičius ${ }^{\star * *}$}

\author{
*Covenant University, Canaanland, Nigeria \\ **Atilim University, Ankara, Turkey \\ E-mail: sanjay.misra@atilim.edu.tr \\ ***Kaunas University of Technology, Kaunas, Lithuania \\ E-mail: robertas.damasevicius@ktu.lt
}

\begin{abstract}
The limited supply of fossil fuels, constant rise in the demand of energy and the importance of reducing greenhouse emissions has brought about the adoption of renewable energy sources for generation of electrical power. In this paper, the impact of renewable energy generation in Nigeria is explored. A review of renewable deposits in Nigeria with a focus on Solar, Biomass, Hydropower, Pumped Storage Hydro and Ocean energy is detailed. The impact of renewable energy-based generation is assessed from three different dimensions: Economic Impact, Social Impact and Environmental Impact. In accessing economic impact; the conditions are employment and job creation, gross domestic product (GDP) growth and increase in local research and development. To analyze the social impact; renewable energy education, renewable energy businesses, ministries and institutes, renewable energy projects and investments as well as specific solar and wind projects across Nigeria were considered. Also, environmental issues were discussed. Similarly, policy imperatives for renewable energy generation in Nigeria was provided. This paper would be useful in accessing the successes Nigeria has experienced so far in the area of sustainable development and the next steps to achieving universal energy for all in Nigeria in 2030.
\end{abstract}

Key words: solar energy, biomass, hydropower, ocean energy, sustainability, thermal energy, economic impact, social impact, environmental impact, renewable energy, West Africa, Nigeria

\section{Streszczenie}

Ograniczona podaż paliw kopalnych, stały wzrost zapotrzebowania na energię oraz konieczność ograniczenia emisji gazów cieplarnianych pociągnęły za sobą konieczność stosowania odnawialnych źródeł energii do wytwarzania energii elektrycznej. W artykule zbadano wpływ wytwarzania energii odnawialnej w Nigerii. Szczegółowy przegląd zasobów energii odnawialnej w Nigerii, ze szczególnym uwzględnieniem energii słonecznej, biomasy, energii wodnej i elektrowni szczytowo-pompowych i energii oceanicznej. Produkcja energii ze źródeł odnawialnych została przeanalizowana w trzech różnych wymiarach: wpływ na gospodarkę, wpływ na społeczeństwo i wpływ na środowisko. W aspekcie wpływu na gospodarkę wzięto pod uwagę: zatrudnienie i tworzenie miejsc pracy, wzrost produktu krajowego brutto (PKB) oraz wzrost lokalnych badań i rozwój. Analiza wpływu społecznego objęła: edukację w zakresie energii odnawialnej, przedsiębiorstwa, ministerstwa i instytuty zajmujące się energią odnawialną, projekty i inwestycje w zakresie energii odnawialnej, a także konkretne projekty dotyczące energii słonecznej i wiatrowej w całej Nigerii. Omówiono również kwestie środowiskowe. W podobny sposób przedstawiono imperatywy polityczne dotyczące wytwarzania energii odnawialnej w Nigerii. 
Ten artykuł wskazuje na istotny dla Nigerii cel zrównoważonego rozwoju, jakim jest odnawialna energia dla wszystkich. Celem jest osiągnięcie w tym kraju powszechnej odnawialnej energii dla wszystkich w $2030 \mathrm{r}$.

Słowa kluczowe: energia słoneczna, biomasa, energia wody, energia oceanu, zrównoważoność, energia cieplna, ekonomia, społeczeństwo, środowisko, energia odnawialna, Afryka Zachodnia, Nigeria

\section{Introduction}

Energy is the cornerstone and essential ingredient of any strategic plan in any nation that focuses at achieving sustainable development in all facets of life and its open access is a means to facilitate any developmental initiative (Xue et al., 2020). Nigeria is undoubtedly an energy resource rich country, yet the Nigeria's energy industry is perhaps inefficient in meeting the energy needs of her citizenry (Dioha, Emodi, Mathew, \& Dioha, 2018; Osueke \& Ezugwu, 2011) (John, Ucheaga, Olowo, Badejo, \& Atayero, 2017). This is because Nigeria's energy supply is heavily dependent on fossil fuel and this sector for about two decades or more has experienced weighty bombardments and these have led services whose operations are dependent on the energy supplied from this sector to experience frequent or total shutdown. Sequel to this, communities that would have been connected to the power grid are left unconnected due to inadequate power generated; hence increasing the country's energy poverty profile. Furthermore, less than 7,000 MW of electricity is being generated from the available sources for about 196 million people in 2018 (Thomas et al., 2019) (Indicators, 2020). This of course, has weakened the zeal to achieve industrialization and consequently economic growth has outlined in vision 2020 (Akin, 2008). Nevertheless, full utilization of available energy sources will facilitate sustainable development and improve the general wellbeing of people especially in the rural areas. It is true that access to energy is expedient to successful national development such as those for health, education, rural development and agriculture and assist in improving a better living condition (E. Okewu, 2017).

Energy poverty is the lack of access to modern energy services. These services are defined as household access to electricity and clean cooking facilities (e.g. fuels and stoves that do not cause air pollution in houses). A review of papers reveals that there are billions of people living without electricity worldwide (Moss \& Bazilian, 2018; Raworth, 2012; Smalley, 2005; Zahnd et al., 2018). The vast majority of people in this category reside in SubSahara Africa (SSA) and South Asia. It is said that an overwhelming estimation of 2.7 billion people rely on traditional biomass for cooking, while 1.4 billion people are not connected to the energy grid (Karekezi, McDade, Boardman, \& Kimani, 2012). Energy poverty is one of the prevailing problems in Sub-Saharan Africa.

Access to energy is a prerequisite for human development. Energy is needed for individual survival, it is important for the provision of social services such as education and health and a critical input into all economic sectors from household production or farming, to industry. Historically, many researchers and development organizations agree that the wealth and development status of a nation and its inhabitants is closely correlated to the type and extent of access to energy. The more access to usable energy and the more efficient energy converting technologies are available, the better the conditions for development of individuals, households, communities, the society and its economy (Day, Walker, \& Simcock, 2016; Sørensen, 2012). Thus, improving access to energy is a continuous challenge for governments and development organizations(Energy Poverty, 2016).

The total estimated grid generation in SSA is about 90 gigawatts (GW), South Africa alone generates half of this, leaving the remaining half to the rest of SSA (Power People Planet, 2015). South Korea produces more electricity and her population is only 5 percent of SSA. The gulf in generation is alarming. Nigeria's electricity generation is about one-quarter of the electricity produced in Vietnam, for a population that is twice the size of Vietnam. Even within Africa, an average South African consumes nine times more energy than a Nigerian. It is important to note that Nigeria's population is three times the size of South Africa's population (Dai, 2015).

With the exception of South Africa, the average energy consumption in SSA is $162 \mathrm{kWh}$ per capita per year. The global world's average is $7000 \mathrm{kWh}$ (Power People Planet, 2015). An average Tanzanian will take around eight years to consume as much electricity as an American consumes in a month (Power People Planet, 2015). Even oil exporting super powers like Nigeria is not left out of this dismal trend, 93 million Nigerians do not have access to electricity (Power People Planet, 2015). Although Angola has five times the average income level of Bangladesh, Bangladesh has far higher access to electricity in the ratio 55:35 percent (Power People Planet, 2015).

It is estimated that if Africa continues to move at the current trends, universal electricity access for all in Africa would be until the year 2080. Some of the contributing factors to Africa's poorly developed energy systems include waste of resources, high dependence on centralized energy systems that favors the rich and bypasses the poor, corruption, energy-sector bureaucracy amongst others. Despite all these challenges, Africa's poorest people pay one of the highest energy tariffs in the 
world. The Africa's panel for Progress estimates that about 138 million households in Africa comprises of people who spend US $\$ 10$ billion yearly on energy related products like candles, charcoal, kerosene and firewood and live on less than US $\$ 2.50$ per day (Power People Planet, 2015). Comparing energy costs between African countries and the United States, the average cost of electricity in the US is US \$0.12 per $\mathrm{kWh}$ and is US \$0.15 in the $\mathrm{UK}$, whereas in Africa around US $\$ 10$ per $\mathrm{kWh}$ is spent only on lighting (Power People Planet, 2015). Some of the solutions brought forward to combat the Energy Poverty situation experienced in SubSaharan Africa include:

- Leapfrogging centralized generation for distributed generation (Levin \& Thomas, 2016; Mandelli \& Mereu, 2013; Murenzi \& Ustun, 2015; Sebitosi \& Okou, 2010; Szabó, Bódis, Huld, \& Moner-Girona, 2013);

- Decentralize the burdened national grid network as a way of ensuring the sustainable delivery of power to consumer (Ambode targets 3000 MW 24-hr power generation for Lagos, 2017);

- Optimally utilize available energy resources which is central to all aspects of the life of any nation (Sambo, 2008);

- To do an extensive investigation of the technical and economic benefits of new integrated renewable systems, especially for communities yet to be connected to the grid.

In this paper, an investigation of the impact of the factors responsible for facilitating renewable energybased generation in Nigeria would be conducted. An attempt to providing tangible solutions to sustainability issues and energy access in the region would be conducted. Section 2 provides a breakdown of renewable deposits in Nigeria with a focus on Solar Power, Biomass and Ocean Energy would be discussed. Section 3 details the Economic Impact of Renewable Energy in Nigeria, focuses on the Social Impact of Renewable Energy Generation in Nigeria with considerations to Renewable Energy Education in Nigeria, Business, Ministries, Institutes and Investments in Nigeria; and the Environmental Impact of renewable energy generation. Section 4 details policy imperatives for renewable energy generation in Nigeria and Section 5 concludes the paper.

\section{Renewable Energy Potentials in Nigeria}

In this section, the Renewable Energy Potentials in Nigeria are explored and discussed. The Renewable energy deposits discussed are Solar, Biomass, Hydropower and Pumped Storage Hydro (PSH), and Ocean Energy.

\section{i. Solar}

Based on Nigeria's location on the Sunshine belt, her Solar energy potentials are enormous. Figure 1 shows the Nigeria solar radiation map. The solar intensity in Nigeria ranges per region between 3.5 $\mathrm{kW} / \mathrm{m} /$ day $-7.0 \mathrm{~kW} / \mathrm{m} /$ day. By covering just $1 \%$ of the Nigeria's land area with solar modules, it would be possible to generate $1850 \times 10^{3} \mathrm{GWh}$ of solar electricity per year. This value is more than 100 times the current energy consumption in Nigeria (Charles, 2014). For the entire landmass of Nigeria, the average solar energy over a year would be 6,372,613 PJ/year (approximately 1770 thousand TWh/year)(Olayinka S. Ohunakin, 2014); that is about 120 thousand times the total electrical energy generated by the PHCN in 2012. Geographically, the annual average solar radiation is about $12.6 \mathrm{MJ} / \mathrm{m}^{2}$ day and $25.2 \mathrm{MJ} / \mathrm{m}^{2}$-day in the costal and northern region respectively (Akuru, Onukwube, Okoro, \& Obe, 2017). According to Nigerian Bulk Electricity Trading company (NBET), as at the 10th of November 2015, there was around 8 PPAs who had indicated their interests in developing Solar power projects (Isoken G. Idemudia, 2016).

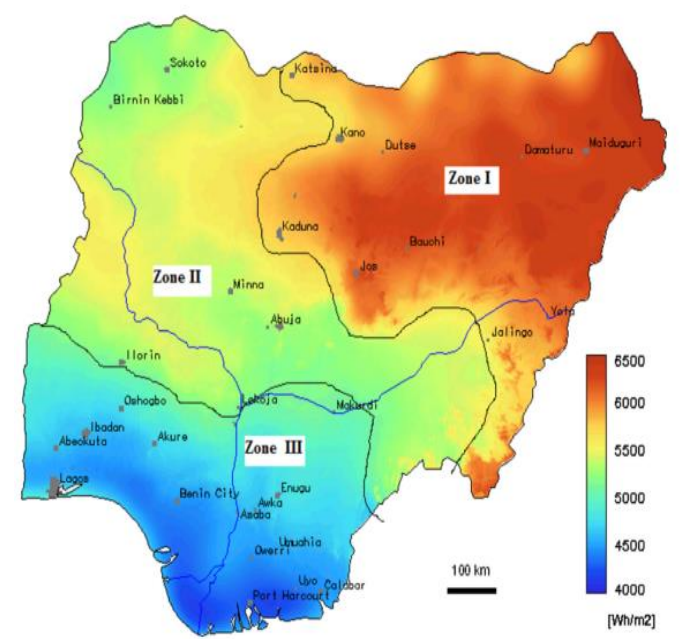

Figure 1. Nigeria's Solar Radiation Map (Olayinka S. Ohunakin, 2014)

\section{ii. Biomass}

Bio-based renewable energy fuels otherwise known as Combustible renewables and wastes exists in 3 states solids, liquids and gases.

Solid biofuels consist of wood, wood waste, twig, leaves, chips, materials generated from the wood and paper industry, nut shells, rice husk, fibrous wastes; these materials are directly burned or converted in to low quality gas in a small low technology anaerobic tank digester.

Nigeria produces about 227,500 tons of fresh animal waste daily (Charles, 2014). By estimation, $1 \mathrm{~kg}$ of fresh animal wastes produces $0.03 \mathrm{~m}^{3}$ of biogas. This means that Nigeria can produce 6.8 million $\mathrm{m}^{3}$ of biogas daily from animal waste only. 
Nigeria's land area distribution includes (get values of land distribution): Forests and Woodlands- $16 \%$, Permanent Pasture $-42 \%$, Arable land - $33 \%$, Permanent crops $-3 \%$, Others $-6 \%$

Assuming that the High heating value (HHV) of wood less the latent heat of vaporization of produced water is $18 \mathrm{MJ} / \mathrm{kg}$. If only 10 percent of the arable land $(3,020,000 \mathrm{ha})$ is used for energy production, 574 PJ of energy or 12.8 Mtoe (million tonnes oil equivalent) would be produced.

\section{iii. Hydropower and Pumped Storage Hydro (PSH)}

In Nigeria, Hydropower is the most exploited renewable power generation option. This exploitation started as far back as 1968 when 8 units where commissioned with a total generation capacity of 760 MW. Combining river Kaduna (Shiroro), Benue (Makurdi) and Cross River (Ikom) indicated that total capacity of about $4,650 \mathrm{MW}$ is available and also the Mambilla plateau is estimated to be 2,330 MW. Small hydropower sources have also been underdeveloped in Nigeria. There are over 278 SHP sites that have not been developed in Nigeria, totaling in 734.3 MW potential capacity; only $3 \mathrm{MW}$ of these has been exploited. In June 2016, the minister of Power, Works and Housing, Babatunde Fashola, inaugurated a committee tasked with the responsibility of identifying and developing plans for the exploitation of SHP in rural communities in Nigeria. 8 locations have been decided upon to constitute the first leg of the pilot study, the locations are Tiga, Challawa dams in Kano-State, Omi-Kampe in Kogi State, Jibiya, Zone dams in Katsina, Bakalori in Zamfara state, Doma in Nassarawa State and Ikere Gorge in Oyo-State (Federal Government Energize Rural Communities with Small Hydros, 2016).

Pumped storage hydro plant is established machinery for energy storage. It stores potential energy from water that is raised against gravity. The first of its kind was constructed in the early $20^{\text {th }}$ century in Schaffhausen, Switzerland. This system was started in 1909 and is still working up till now. As years go by, pumped storage hydro system becomes more attractive and recently it was heavily employed for supplying peak energy (Torres, 2011).

Nowadays, PSH is the most widely used method of mini hydroelectric power systems and is becoming domineering because of its cost effectiveness. I $t$ does not require building a base load plant to cushion the effect of peak demand; instead the peak load demand is taking care of by increasing the peak hydro power production via pumping the already used water from the underground reservoir into the overhead reservoir using the excess electricity during the offpeak period. This can be achieved by swiftly configuring the generator to work as a motor for pumping up water during the trough periods (Jayesh, Arun, Patil, \& Shailendra, 2013). It stores energy in the form of water in an upper reservoir during low electricity demand and during the high electricity demand; the stored water is released through the penstock to the power house via the turbine where electrical power is generated in the same way as conventional hydro power plants(Association, 2016).

According to the water flow and capacities that can be generated in Nigeria, PSH can be categorized into:

- Mini hydro $-\geq 100 \mathrm{~kW} \leq 2 \mathrm{MW}$

- micro hydro $-\geq 5 \mathrm{~kW} \leq 100 \mathrm{~kW}$

- Pico hydro $-<5 \mathrm{~kW}$

The aforementioned types of PSH can also be a runof-river type. This means that there is no water storage for electricity generation. Moreover, the water for electricity generation is sidetracked from a river via a barrier. The run-of-river type of electricity generation is more profitable for a Pico hydro power generation because it reduces the investment cost per KW of electricity (Chiyembekezo, Cuthbert, \& Torbjorn, 2012). PSH is a good prospect for a better electricity future to rural communities across Nigeria and for replacing every other unhealthy means of energy generation for the purpose of lighting, warming, cooling, powering radios, TVs and machinery, and providing other livelihood opportunities. The heart of a PSH is the turbine, which drives an alternator for electricity generation. Table 1 provides the potential Small Hydro sites in Nigeria.

Table 1. Small Hydro Potential in surveyed states in Nigeria (Manohar \& Adeyanju, 2009)

\begin{tabular}{|l|c|c|c|}
\hline $\begin{array}{l}\text { State } \\
\text { (Pre 1980) }\end{array}$ & River Basin & $\begin{array}{l}\text { Total } \\
\text { Sites }\end{array}$ & $\begin{array}{l}\text { Total } \\
\text { Capacity }\end{array}$ \\
\hline Sokoto & Sokoto-Rima & 22 & 30.6 \\
\hline Katsina & Sokoto-Rima & 11 & 8.0 \\
\hline Niger & Niger & 30 & 117.6 \\
\hline Kaduna & Niger & 19 & 59.2 \\
\hline Kwara & Niger & 12 & 38.8 \\
\hline Kano & $\begin{array}{c}\text { Hadeija-Ja- } \\
\text { maare }\end{array}$ & 28 & 46.2 \\
\hline Borno & Chad & 28 & 20.8 \\
\hline Bauchi & Upper Benue & 20 & 42.6 \\
\hline Gongola & Upper Benue & 38 & 162.7 \\
\hline Plateau & Lower Benue & 32 & 110.4 \\
\hline Benue & Lower Benue & 19 & 69.2 \\
\hline Rivers & Cross River & 18 & 258.1 \\
\hline Total & & 277 & 734.2 \\
\hline
\end{tabular}

\section{iv. Ocean}

Nigeria has an approximate value of $834 \mathrm{~km}$ coastline that runs through seven states. These states are Ogun, Ondo, Akwa-Ibom, Bayelsa, Cross-rivers, Lagos, and Rivers bordering the Atlantic Ocean. The Bight of Bonny, Bight of Benin, Cross River Estuaries and Lagos lagoon are a few of the water bodies that holds the potential to operate an OBRE. Table 2 shows the wave characteristics of these locations. Different ocean forces such as the tides, salinity, current etc. can be used to generate electricity. 
Table 2. Wave characteristics of different ocean bodies in Nigeria

\begin{tabular}{|l|c|c|}
\hline Location & $\begin{array}{c}\text { Highest mean } \\
\text { wind speed } \\
\text { (knots) }\end{array}$ & $\begin{array}{c}\text { Highest mean } \\
\text { wave height (m) }\end{array}$ \\
\hline $\begin{array}{l}\text { Bight of } \\
\text { Bonny }\end{array}$ & 7.5 & 1.24 \\
\hline $\begin{array}{l}\text { Bight of } \\
\text { Benin }\end{array}$ & 7.6 & 1.4 \\
\hline $\begin{array}{l}\text { Cross River } \\
\text { Estuaries }\end{array}$ & 5.6 & 0.9 \\
\hline
\end{tabular}

\section{Various Factors affecting Renewable Energy Generation}

There are three important pillars of sustainable development - Economic, social and environmental, which majorly affect renewable energy generation. In the following sections we are providing them in details.

\subsection{Economic Impact of Renewable Energy Gener- ation in Nigeria}

Some of the economic impacts of renewable energy generation are diversification of energy supply, increased urban, peri-urban and rural development opportunities, development of local industry and increased employment opportunities. It is expected that with the increase in energy generation via the inclusion of renewable energy generation; income distribution would be widespread and impact on tourism would be increased (Del Río \& Burguillo, 2008) (E. Okewu, Misra S., Fernandez S.L., Maskeliunas R., \& Damasevicius R,, 2018).

\section{i. Gross Domestic Product (GDP) growth}

Increased Energy generation would undoubtedly increase productivity and economic growth of a nation (John et al., 2017). Increased industry presence and output would facilitate the growth of GDP of the nation.

\section{ii. Increase in Local Research and Develop- ment}

One of the industries lacking in Nigeria is Research and Development, it is expected that with increase in RE generation, the need for companies focused on Research and Development would be on the increase. This would thereby lead to an increase in job creation and economic growth.

\subsection{Social Impact of Renewable Energy Genera- tion in Nigeria}

In this section, the social impacts of renewable energy generation in Nigeria is discussed with a focus on Employment and job creation Renewable energy education, Renewable energy businesses, ministries, and institutes, renewable energy projects and investments as well as specific solar and wind projects across Nigeria.

\section{i. $\quad$ Employment and Job Creation}

Based on literature, renewable energy projects have a significant effect on employment and job creation. In Nigeria, several renewable energy companies have arisen in recent years and these have increased the demand for both skilled and un-skilled labor in RE development.

\section{ii. $\quad$ Renewable Energy Education in Nigeria}

The increase in Renewable Energy generation has increased the need to train local workers on specific trainings. Some of these may require informal education and others may require a more formal educational setup. In a bid to train the next generation of renewable energy specialists and engineers in Nigeria, a number of renewable energy type programs are being hosted in Nigerian Tertiary Institutions.

Data on engineering programs offered by Nigerian Tertiary Institutions (NTI) - Universities and Polytechnics relating to Renewable energy was analyzed. The analysis reveals the proliferation of these engineering programs in NTIs and other programs of interest that could be developed. The following programs are considered in this analysis Climate engineering, Control engineering, Electrical/Electronics, Electrical, Electronics, Electromechanical, Energy Engineering, Engineering Physics, Engineering Science, Information Technology (IT) Engineering, Information Engineering, Mechanical, Mechatronics, and Power Distribution Engineering.

We analyzed 48 NTIs reported to offer engineering programs. We further analyzed the data to reveal only Nigerian Universities with the above listed Renewable Energy type programs. Out the 48 NTIs, 47 reported to having a minimum of one (1) renewable energy type program and a maximum of five (5) renewable energy type program. The results also show an average of 2.586 engineering programs per university. A total of 150 renewable energy programs in the 48 NTIs under observation. Appendix 1 shows Universities in Nigeria and the number of renewable engineering type programs they offer.

\section{iii. Businesses, Ministries, Institutes and In- vestments}

The emergence of Renewable energy generation has led to an increase in Renewable Energy pilot projects, businesses and investments across Nigeria. Table 3 provides a lists of renewable energy ministries and institutes in Nigeria; Table 4 shows a list of renewable projects and investments across Nigeria and Table 5 provides a list of specific wind and solar projects across Nigeria.

\subsection{Environmental Impact of Renewable Energy Generation in Nigeria}

Some of the environmental issues with renewable energy are air pollution, water pollution, damage to biodiversity (wildlife and plant life), damage to hab- 


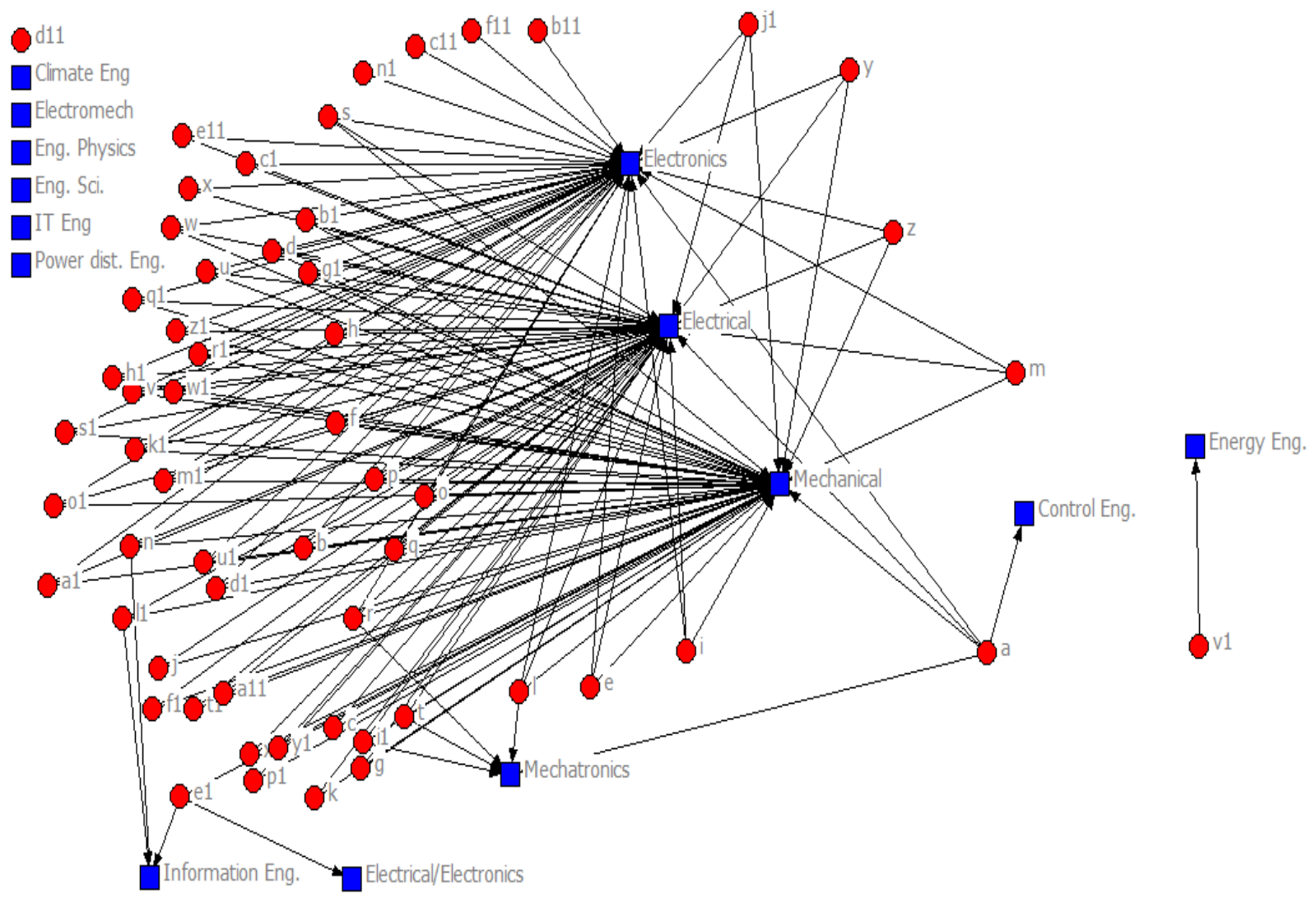

Figure 2. Network of Tertiary Institutions in Nigeria and Renewable Energy Related Projects

Table 3. Renewable Energy Ministries and Institutes in Nigeria

\begin{tabular}{|c|c|c|c|c|}
\hline Author & State & Year & Ministry/Institute & Activities \\
\hline \multirow[t]{4}{*}{$\begin{array}{l}\text { (Osunmuyiwa \& } \\
\text { Kalfagianni, } \\
\text { 2017) }\end{array}$} & Delta & 2007 & $\begin{array}{l}\text { Two institutions on energy } \\
\text { (Delta Green Economy } \\
\text { Commission, Rural Devel- } \\
\text { opment Agency) }\end{array}$ & $\begin{array}{l}\text { Development of renewables and rural elec- } \\
\text { trification }\end{array}$ \\
\hline & Lagos & 2009 & $\begin{array}{l}\text { Lagos Waste Management } \\
\text { Authority (LAWMA) }\end{array}$ & $\begin{array}{l}\text { First created in the } 1970 \text { 's, the ministry } \\
\text { was created to handle to large amount of } \\
\text { municipal waste generated in the state for } \\
\text { energy generation }\end{array}$ \\
\hline & Sokoto & 2009 & Ministry of Environment & Deployment of renewable technologies \\
\hline & Lagos & 2011 & $\begin{array}{l}\text { Ministry of Energy and } \\
\text { Mineral Resources }\end{array}$ & $\begin{array}{l}\text { Saddled with the responsibility of design- } \\
\text { ing an energy master plan with renewable } \\
\text { energy development at the core }\end{array}$ \\
\hline \multirow[t]{5}{*}{$\begin{array}{l}\text { ECN, } 2017 \\
\text { ("Research } \\
\text { Centres," 2007) }\end{array}$} & $\begin{array}{l}\text { University of } \\
\text { Nigeria, } \\
\text { Nsukka, Enugu }\end{array}$ & & $\begin{array}{l}\text { National Centre for Energy } \\
\text { Research and Development }\end{array}$ & Research in Solar and Renewable Energy \\
\hline & $\begin{array}{l}\text { Usmanu Dan- } \\
\text { fodiyo Univer- } \\
\text { sity, Sokoto }\end{array}$ & & $\begin{array}{l}\text { Sokoto Energy Research } \\
\text { Centre (SERC) }\end{array}$ & Research in Solar and Renewable Energy \\
\hline & $\begin{array}{l}\text { University of } \\
\text { Lagos }\end{array}$ & & $\begin{array}{l}\text { National Centre for Energy } \\
\text { Efficiency and Conserva- } \\
\text { tion (NCEEC) }\end{array}$ & $\begin{array}{l}\text { Research in energy efficiency and conser- } \\
\text { vation }\end{array}$ \\
\hline & $\begin{array}{l}\text { University of } \\
\text { Ilorin }\end{array}$ & & $\begin{array}{l}\text { National Centre for Hydro- } \\
\text { power Research and Devel- } \\
\text { opment (NCHRD) }\end{array}$ & Responsible for research in Hydropower \\
\hline & $\begin{array}{l}\text { Abubakar Ta- } \\
\text { fawa Balewa } \\
\text { University, } \\
\text { Bauchi }\end{array}$ & & $\begin{array}{l}\text { National Centre for Petro- } \\
\text { leum Research and Devel- } \\
\text { opment (NCPRD) }\end{array}$ & $\begin{array}{l}\text { Responsible for research in petroleum oil } \\
\text { and gas }\end{array}$ \\
\hline
\end{tabular}


Table 4. Renewable Energy Projects and Investments in Nigeria

\begin{tabular}{|c|c|c|c|c|}
\hline Author & $\begin{array}{l}\text { Project } \\
\text { Name }\end{array}$ & Pilot Location & $\begin{array}{l}\text { Collaborating Compa- } \\
\text { nies or ministries and } \\
\text { Location }\end{array}$ & Scope \\
\hline \multirow[t]{9}{*}{$\begin{array}{l}\text { (Osunmuyiwa } \\
\text { \& Kalfagianni, } \\
\text { 2017) }\end{array}$} & 2014 & Lagos & $\begin{array}{l}\text { Total Energy Group } \\
\text { and the Lagos State } \\
\text { Government }\end{array}$ & $\begin{array}{l}\text { A } 1.5 \text { million USD solar powered service } \\
\text { station in Lagos }\end{array}$ \\
\hline & 2012 & Lagos & $\begin{array}{l}\text { Schneider, Siemens } \\
\text { and Lagos State Gov- } \\
\text { ernment }\end{array}$ & $\begin{array}{l}\text { Development of techno-institutional capaci- } \\
\text { ties in the deployment of Renewable Ener- } \\
\text { gies }\end{array}$ \\
\hline & $\begin{array}{l}\text { From } \\
2005\end{array}$ & & $\begin{array}{l}\text { KNX and ZAGO and } \\
\text { the Sokoto State Gov- } \\
\text { ernment }\end{array}$ & $\begin{array}{l}\text { Rural Electrification projects in Sokoto. Es- } \\
\text { pecially the deployment of Solar refrigera- } \\
\text { tors to } 90 \text { rural villages in Northern Nigeria }\end{array}$ \\
\hline & $\begin{array}{l}2012- \\
2014\end{array}$ & $\begin{array}{l}\text { Lagos, Sokoto, } \\
\text { Delta }\end{array}$ & $\begin{array}{l}\text { United Nations De- } \\
\text { velopment Pro- } \\
\text { gramme (UNDP) and } \\
\text { Bank of Industry } \\
\text { (BoI) }\end{array}$ & $\begin{array}{l}\text { Invested US } \$ 4780 \text { million on financing re- } \\
\text { newable energy projects in these states in } \\
\text { order to facilitate the growth of micro, } \\
\text { small and medium enterprises in the states }\end{array}$ \\
\hline & & Lagos & $\begin{array}{l}\text { Ifelodun/Ojokoro Co- } \\
\text { operative Multipur- } \\
\text { pose Agricultural So- } \\
\text { ciety }\end{array}$ & $\begin{array}{l}\text { Initiate the deployment of a } 18 \mathrm{~m} 3 \text { pig dung } \\
\text { biogas plant in Lagos }\end{array}$ \\
\hline & & Ibadan & $\begin{array}{l}\text { International Institute } \\
\text { for Tropical Agricul- } \\
\text { tural (IITA) }\end{array}$ & Development of biofuel project \\
\hline & & Enugu & $\begin{array}{l}\text { National Centre for } \\
\text { Energy Research and } \\
\text { Development }\end{array}$ & $\begin{array}{l}\text { Several pilot scale solar water hearters and } \\
\text { solar dryers, National Stove Eligibility la- } \\
\text { boratory funded by the Global alliances for } \\
\text { Cook Stoves }\end{array}$ \\
\hline & 2009 & Bauchi $* *$ & $\begin{array}{l}\text { Bauchi State Govern- } \\
\text { ment and Chinese } \\
\text { equipment corpora- } \\
\text { tion }\end{array}$ & $\begin{array}{l}\text { Deployment of Power generating plants for } \\
\text { use in rural communities }\end{array}$ \\
\hline & & Bauchi $* *$ & $\begin{array}{l}\text { Bauchi State Govern- } \\
\text { ment and German } \\
\text { company, Helior En- } \\
\text { ergie }\end{array}$ & $\begin{array}{l}\text { Generation of } 20-30 \mathrm{MW} \text { of energy through } \\
\text { solar power }\end{array}$ \\
\hline
\end{tabular}

** states has no renewable energy agency, ministry or policy

Table 5. Specific Solar and Wind Power Project across Nigeria

\begin{tabular}{|c|c|c|c|}
\hline Technology/System & \multicolumn{2}{|c|}{ 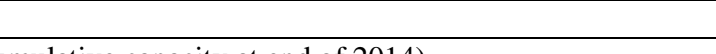 } & Additional Information \\
\hline \multicolumn{4}{|c|}{ Based on REN 21 (2015) (cumulative capacity at end of 2014) } \\
\hline \multirow[t]{3}{*}{ (Rainer Quitzow, 2016) } & Mini-grid (solar) & & 6 units \\
\hline & Mini-grid (solar) & & $\begin{array}{l}4 \mathrm{kWp}, 150 \text { residents electri- } \\
\text { fied }\end{array}$ \\
\hline & Hybrid mini-grid & & $\begin{array}{l}16 \mathrm{kWp}, 12 \text { Compact mini- } \\
\text { grid }\end{array}$ \\
\hline \multicolumn{4}{|l|}{ Based on IRENA (2015 e) } \\
\hline \multirow[t]{2}{*}{ Mini-grid } & Mini-grid & & $\begin{array}{l}6 \text { units, } 700 \text { households elec- } \\
\text { trified }\end{array}$ \\
\hline & \multicolumn{3}{|l|}{ Journal reports } \\
\hline \multirow{9}{*}{$\begin{array}{ll}\text { (Chiemeka } & \text { Onyeka } \\
\text { Okoye, 2015) } & \end{array}$} & Solar Street Lights & Ado Ekiti (South-West) & \\
\hline & $\begin{array}{l}\text { Kwalkwalana village elec- } \\
\text { trification }\end{array}$ & Sokoto (North) & $7.2 \mathrm{~kW}_{\mathrm{p}}$ \\
\hline & $\begin{array}{l}\text { Nangere water pumping } \\
\text { scheme }\end{array}$ & Sokoto, North & $1.5 \mathrm{~kW}_{\mathrm{p}}$ \\
\hline & Solar Rice Dryer & Adani, Enugu, South-East & 2 tonne \\
\hline & $\begin{array}{l}\text { Iheakpu-Awka village } \\
\text { electrification }\end{array}$ & Enugu, south-east & $1.9 \mathrm{~kW}_{\mathrm{p}}$ \\
\hline & Solar Forage Dryer & Yauri, Kebbi North & 1.5 tonne \\
\hline & Solar Energy Plant & Katsina, North & $20 \mathrm{MW}_{\mathrm{p}}$ \\
\hline & Solar farm & Katsina, North & $50 \mathrm{MW}_{\mathrm{p}} ;$ Synergent Group \\
\hline & Solar power plant & Katsina, North & $\begin{array}{l}60 \mathrm{MW}_{\mathrm{p}} \text {, (Nigeria-German } \\
\text { Energy Partnership) }\end{array}$ \\
\hline
\end{tabular}




\begin{tabular}{|c|c|c|c|}
\hline & $\begin{array}{l}\text { Solar farm (Nigeria Solar } \\
\text { Capital Project and Giga- } \\
\text { watt solar) }\end{array}$ & Bauchi, North & $\begin{array}{l}100 \mathrm{MW}_{\mathrm{p}} \text { (Nigeria Solar } \\
\text { Capital Project and Gigawatt } \\
\text { solar) }\end{array}$ \\
\hline \multirow[t]{18}{*}{$\begin{array}{l}\text { (Olayinka S. Ohunakin, } \\
\text { 2014) }\end{array}$} & $\begin{array}{l}\text { Solar based rural electrifi- } \\
\text { cation }\end{array}$ & Oporoma, Ekawe & Bayelsa \\
\hline & $\begin{array}{l}\text { Solar based rural electrifi- } \\
\text { cation }\end{array}$ & $\begin{array}{l}\text { Ekowe, Egwuma, Okokolo, } \\
\text { Ogbanlu, Ekwo, Enungba, Ojan- } \\
\text { tele, Ikobi, Adija, Usha, } \\
\text { Egwuma }\end{array}$ & Benue \\
\hline & Solar Plant & Evwreni, Ughelli North LGA & Delta \\
\hline & $\begin{array}{l}\text { Solar based rural electrifi- } \\
\text { cation }\end{array}$ & Ibuza & Delta \\
\hline & $\begin{array}{l}\text { Solar based rural electrifi- } \\
\text { cation }\end{array}$ & Filin-dabo & FCT \\
\hline & $\begin{array}{l}\text { Development of a farm for } \\
\text { bio fuel production }\end{array}$ & Abuja & FCT \\
\hline & Solar pilot project & Malam Inna & Gombe \\
\hline & $\begin{array}{l}\text { Solar based rural electrifi- } \\
\text { cation }\end{array}$ & $\begin{array}{l}\text { Laya, Sakura, Sharhori, Tudun } \\
\text { Wada, Dabau }\end{array}$ & Jigawa \\
\hline & $\begin{array}{l}\text { Solar based rural electrifi- } \\
\text { cation }\end{array}$ & $\begin{array}{l}\text { Kurmin sata, Chikun, Kasuwan } \\
\text { Daji Igabi, Gubuci, Kudan, Ma- } \\
\text { karfi, Hunkuyi, Panlandan by } \\
\text { Railway, Sokoto Rd Zaria }\end{array}$ & Kaduna \\
\hline & $\begin{array}{l}\text { Solar based rural electrifi- } \\
\text { cation }\end{array}$ & $\begin{array}{l}\text { Kano - Kafur Rd Malumfashi, } \\
\text { Galadima Sallau, Tunai Dudi, } \\
\text { Shawai Rd, Malumfashi, Gala- } \\
\text { dima Abu, BCGA-Dan Murubo } \\
\text { Rd, Borin Dawa Muntari Abu- } \\
\text { bakar Rd Malumfashi, Danbi- } \\
\text { lagu Unguwar Makera, Malum- } \\
\text { fashi Danbilagu Unguwar Ma- } \\
\text { kera (II), Malumfashi, Birin } \\
\text { Kogo, Faskari, Sirika B, Dutsi } \\
\text { LGA, Galadima Abu, } \\
\text { BCGA_Dan Murubo Rd, Ma- } \\
\text { lumfashi, Birin Kogo }\end{array}$ & Katsina \\
\hline & $\begin{array}{l}\text { Wind energy foe electric } \\
\text { power generation }\end{array}$ & Kebbi, Yauri & Kebbi \\
\hline & Solar based street lighting & $\begin{array}{l}\text { Adeyemi Street Ogun Oloko, } \\
\text { Mafoluku Oja }\end{array}$ & Lagos \\
\hline & $\begin{array}{l}\text { Solar based rural electrifi- } \\
\text { cation }\end{array}$ & $\begin{array}{l}\text { Old Muri and Environs, Palace } \\
\text { way to Comprehensive Sec. Sch, } \\
\text { Behind SSS office Jalingo, Tella } \\
\text { village }\end{array}$ & Taraba \\
\hline & $\begin{array}{l}1565 \mathrm{kWp} \text { Solar-powered } \\
\text { borehole and street light- } \\
\text { ing }\end{array}$ & $\begin{array}{l}\text { Malarin Gamma Village, Malam } \\
\text { Madori LGA }\end{array}$ & Jigawa \\
\hline & $\begin{array}{l}1820 \mathrm{kWp} \text { Rural solar } \\
\text { electrification project }\end{array}$ & Gui, AMAC & FCT \\
\hline & $\begin{array}{l}2.85 \mathrm{kWp} \text { solar based elec- } \\
\text { trification }\end{array}$ & $\begin{array}{l}\text { Centre for Mentally ill Destitute, } \\
\text { Itumbuzo }\end{array}$ & Abia \\
\hline & $\begin{array}{l}1.75 \mathrm{kWp} \text { solar based elec- } \\
\text { tricity and street lighting }\end{array}$ & Ini LGA Secretariat & Akwa Ibom \\
\hline & $\begin{array}{l}7.5 \text { centralized solar po- } \\
\text { wer plant }\end{array}$ & $\begin{array}{l}\text { Oduduwa road, University of } \\
\text { Ibadan }\end{array}$ & Oyo state \\
\hline Journal reports & \multicolumn{3}{|l|}{ Journal reports } \\
\hline Technology/system & & & Additional information \\
\hline
\end{tabular}

itat, global warming etc. It should be noted that air pollution also affects economic growth of a nation (John, Ucheaga, Badejo, \& Atayero, 2018) (E. Okewu, Misra S., Fernandez S.L., Ayeni F., Mbarika V., \& Damasevicius R,, 2019).
Nigeria has seen many economic changes as well as an evolution in the power generation sector. The $\mathrm{Ni}$ gerian power sector has also undergone privatization in 2013 with the generation and distribution companies being unbundled. The transmission company is still in control of the Federal Government. 


\section{i. $\quad$ Air Pollution}

Some of the main air pollutants are Sulphur oxides, nitrogen oxides and suspended particulates. Globally speaking, Africa has not contributed a lot to global toxic gas emissions (John et al., 2018) due to low levels of industrialization. However, the major sources of air pollution in Nigeria include: Particles from desert zone of the Sahara; Biomass burning that produces huge amounts of black and organic carbon; The use of biofuels resulting in the increase of gaseous air toxins like NOx, CO, Volatile organic compounds (VOC), $\mathrm{SO}_{2}$. This is also associated with combustions in vehicles, domestic power generators and industrial activities.

In Lagos, one of the most populous cities in the world, air pollution due to high population and vehicular activity is on the increase. Table 6 shows the ambient air pollution in traffic areas and non-traffic area in Nigeria in comparison with the Federal Environmental Protection Agency (FEPA) of Nigeria.

Table 6. Ambient air pollution in traffic and non-traffic zones in Nigeria

\begin{tabular}{|l|c|c|c|}
\hline & $\begin{array}{c}\text { Non-traf- } \\
\text { fic urban } \\
\text { zone }\end{array}$ & $\begin{array}{c}\text { Traffic } \\
\text { zone }\end{array}$ & $\begin{array}{c}\text { FEPA } \\
\text { standards }\end{array}$ \\
\hline $\mathrm{TSP} \mu / \mathrm{m}^{3}$ & $\begin{array}{c}31.4- \\
746.5\end{array}$ & $720-950$ & 250 \\
\hline $\begin{array}{l}\mathrm{NOx} \\
(\mathrm{ppm})\end{array}$ & $81-81.5$ & $34-131.6$ & $40-60$ \\
\hline $\begin{array}{l}\mathrm{SO}_{2} \\
(\mathrm{ppm})\end{array}$ & $0.5-43$ & $20-250$ & 100 \\
\hline $\mathrm{CO}(\mathrm{ppm})$ & $0.5-3.9$ & $10-250$ & 10 \\
\hline
\end{tabular}

\section{ii. Damage to biodiversity and habitat}

Asides from the troublesome nature of large land use which comes with grave consequences. Clearing of biodiversity and wildlife life to the reduction in the natural floral or fauna of the land, extinction of rare species and erosion etc. Clearing biodiversity could increase the rate of loss of food, medicine, and other uses of biodiversity by indigenous people; Increase local temperature and the resultant health challenges with emerging diseases pathogens due to warming and Increase cumulative cost of social wellbeing and the antecedent challenges.

\section{Policy Imperatives for Renewable Energy Generation in Nigeria}

Prior to 2005, there was no defined renewable energy plan in Nigeria. In order to fully appreciate the growth of Renewable energy in Nigeria via policy formations and Government interventions, a review of Renewable Energy policies in Nigeria is detailed in Table 7. Accelerating the adoption of renewable energy requires deliberate action backed-up with policy that will enable quick and early decisions.
Policies and schemes that facilitate production of renewable energy products like production-based incentives, tax credit should be encouraged. Feed-in tariff, investments tax credit, value added tax (VAT) exemption, interest-free loan and loan guarantees.

\section{Conclusion}

Going by the reality that the solution to Nigeria's power challenge is not close in sight, the need to conserve and efficiently manage the available power becomes very imperative. Various energy sustainability and efficiency initiatives have been introduced which includes the introduction of CFLs and LEDs lightings, use of energy efficient electrical appliances, use of renewable energy and various Clean energy initiatives.

With the deregulation of the Nigerian Power sector, some of the possible investment opportunities available to members of the business community, industry captains and private investors are provision of renewable energy power generation infrastructure which includes; microgrid development, development of hybrid system, consortium formulation for Independent Power Producers (IPPs) generation and sales of power, sales and maintenance of metering infrastructure, capacity building of young workforce in the area of energy auditing, environmentalists, measurement and verification experts, policy experts etc.

Similarly, Modern energy should be considered as an indispensable necessity and a fundamental right, and should be provided on the basis of justice for the all. Energy should be made a high priority and likewise enshrined in the constitution.

There should be an attitudinal change towards sustainable energy development by the government and willingness to make policies that will stand the test of time. Thus, governments have to consider it as one of their ultimate responsibilities. It is expected that with the increased attention by the government, employment and job creation, gross domestic product (GDP) growth, and local research and development would be on the increase. Also, with regards to renewable energy education, more specialized courses need to be adopted and included in the tertiary institution curriculum. Policy imperatives for achieving increased energy generation was also discussed.

\section{References}

1. AKURU U. B., ONUKWUBE I. E., OKORO O. I., OBE E. S., 2017, Towards $100 \%$ renewable energy in Nigeria, in: Renewable and Sustainable Energy Reviews, 71, p. 943-953.

2. Ambode targets 3000MW 24-hr power generation for Lagos, 2017, Vanguard, February 16, http://www. vanguardngr.com/2017/02/ambode-targets-3000mw24-hr-power-generation-lagos/. 
Table 7. Review of Energy Polices enacted in Nigeria

\begin{tabular}{|c|c|c|c|c|c|}
\hline Author & $\begin{array}{l}\text { Year of Po- } \\
\text { licy formu- } \\
\text { lation }\end{array}$ & $\begin{array}{l}\text { Formulating } \\
\text { body }\end{array}$ & $\begin{array}{l}\text { Policy to take } \\
\text { effect from }\end{array}$ & $\begin{array}{l}\text { Policy } \\
\text { Name }\end{array}$ & Policy Details \\
\hline $\begin{array}{l}\text { (Emodi \& Boo, } \\
\text { 2015) (Mas'ud } \\
\text { et al., 2015) }\end{array}$ & 2005 & ECN & & $\begin{array}{l}\text { Renewable } \\
\text { Energy } \\
\text { Master } \\
\text { Plan } \\
\text { (REMP) }\end{array}$ & $\begin{array}{l}\text { The REMP contains details of the } \\
\text { Government's support for Renewa- } \\
\text { ble energy for all applications. } \\
\text { The need for financial and legal in- } \\
\text { struments, technology development, } \\
\text { raising awareness, capacity building } \\
\text { and education as strategic areas to } \\
\text { be developed. }\end{array}$ \\
\hline $\begin{array}{l}\text { (Emodi \& Boo, } \\
\text { 2015) }\end{array}$ & 2008 & $\begin{array}{l}\text { NERC (Nige- } \\
\text { rian Electricity } \\
\text { Regulation } \\
\text { Commission) }\end{array}$ & $\begin{array}{l}1^{\text {st }} \text { July, } 2008 \\
\text { to } 30^{\text {th }} \text { June, } \\
2013 \text { (with- } \\
\text { drawn in } \\
2012 \text { ) }\end{array}$ & $\begin{array}{l}\text { Multi-Year } \\
\text { Tariff Or- } \\
\text { der } 1 \\
\text { (MYTO 1) }\end{array}$ & $\begin{array}{l}\text { Regulation of prices paid to li- } \\
\text { censed electricity generation com- } \\
\text { panies. } \\
\text { The policy also provided for fiscal } \\
\text { and financial incentives for electric- } \\
\text { ity companies who exploited multi- } \\
\text { ple RE resources. } \\
\text { Feed-in-tariffs and premiums for } \\
\text { small electricity providers as well } \\
\text { as consumers who are able to gen- } \\
\text { erate and sell to utility companies. }\end{array}$ \\
\hline $\begin{array}{l}\text { (Emodi \& Boo, } \\
\text { 2015) }\end{array}$ & 2011 & $\begin{array}{l}\text { ECN \& Fed- } \\
\text { eral Ministry } \\
\text { of Environ- } \\
\text { ment }\end{array}$ & & REMP & $\begin{array}{l}\text { The REMP contained targets from } \\
2015 \text { to } 2030 \text { on renewable energy } \\
\text { contributions to total energy con- } \\
\text { sumption in Nigeria. } \\
\text { It also contains some fiscal and } \\
\text { market incentives to boost develop- } \\
\text { ment and deployment of RE tech- } \\
\text { nology }\end{array}$ \\
\hline $\begin{array}{l}\text { (Emodi \& Boo, } \\
\text { 2015) }\end{array}$ & & & $\begin{array}{l}1^{\text {st }} \text { June } 2012 \\
\text { to } 31^{\text {st }} \text { May } \\
2017\end{array}$ & $\begin{array}{l}\text { Multi-Year } \\
\text { Tariff Or- } \\
\text { der } 2 \\
\text { (MYTO 2) }\end{array}$ & $\begin{array}{l}\text { The retail tariff in MYTO } 2 \text { will be } \\
\text { reviewed bi-annually, prices and } \\
\text { rates would be adjusted based on } \\
\text { Nigerian Inflation rate, US\$ ex- } \\
\text { change rate etc. } \\
\text { It also contains a } 15 \text {-year tariff for } \\
\text { electricity generated from RE. } \\
\text { However, the prices are still nego- } \\
\text { tiable assuming the generator can } \\
\text { show to the NERC that the cost of } \\
\text { generation is not in line with the as- } \\
\text { sumptions }\end{array}$ \\
\hline $\begin{array}{l}\text { (Osunmuyiwa } \\
\text { \& Kalfagianni, } \\
\text { 2017) }\end{array}$ & & $\begin{array}{l}\text { Lagos and So- } \\
\text { koto State } \\
\text { Government }\end{array}$ & 2013 & $\begin{array}{l}\text { Energy } \\
\text { policy on } \\
\text { Renewable } \\
\text { Energy }\end{array}$ & $\begin{array}{l}\text { In Lagos the framework revolved } \\
\text { around ensuring that the } 400 \mathrm{MW} \text { of } \\
\text { energy via renewables was } \\
\text { achieved and } 90 \% \text { use of renewable } \\
\text { by } 2020\end{array}$ \\
\hline
\end{tabular}

\section{Appendix}

Nigerian Tertiary Institutions and the number of Renewable Energy Type Programs they offer

\begin{tabular}{|l|l|}
\hline 5 programs & $\mathrm{a}$ \\
\hline 4 Programs & $\mathrm{r}, \mathrm{n}$ \\
\hline 3 Programs & $\mathrm{b}, \mathrm{q}, \mathrm{h} 1, \mathrm{f}, \mathrm{h}, \mathrm{I}, \mathrm{m} 1, \mathrm{y}, \mathrm{l}, \mathrm{m}, \mathrm{j} 1, \mathrm{o}, \mathrm{p}, \mathrm{e} 1, \mathrm{~g} 1, \mathrm{~s}, \mathrm{t}, \mathrm{u}, \mathrm{v}, \mathrm{w}, \mathrm{l1}, \mathrm{b} 1, \mathrm{z}, \mathrm{a} 1, \mathrm{~s} 1, \mathrm{q} 1, \mathrm{~d} 1, \mathrm{o} 1, \mathrm{i} 1, \mathrm{u} 1, \mathrm{k} 1, \mathrm{z} 1, \mathrm{w} 1$, \\
\hline 2 Programs & $\mathrm{k}, \mathrm{g}, \mathrm{d}, \mathrm{f} 1, \mathrm{j}, \mathrm{c} 1, \mathrm{e}, \mathrm{c}, \mathrm{t} 1, \mathrm{x} 1, \mathrm{y} 1, \mathrm{p} 1, \mathrm{a} 11, \mathrm{e} 11, \mathrm{x}$ \\
\hline 1 Program & $\mathrm{n}, \mathrm{v} 1, \mathrm{c} 11, \mathrm{~b} 11, \mathrm{f} 11$ \\
\hline
\end{tabular}


Key

\begin{tabular}{|c|c|c|c|}
\hline & University & & University \\
\hline $\mathrm{a}$ & $\begin{array}{l}\text { Modibbo Adama University of Technology Yola } \\
\text { (Federal University of Technology) }\end{array}$ & d1 & Federal Polytechnic Nasarawa \\
\hline $\mathrm{b}$ & University of Lagos & $\mathrm{e} 1$ & Covenant University Ota \\
\hline $\mathrm{c}$ & University of Ilorin & $\mathrm{f} 1$ & Federal University of Technology Minna \\
\hline $\mathrm{d}$ & Federal University of Technology Owerri & g1 & Federal University of Agriculture Makurdi \\
\hline $\mathrm{e}$ & Nnamdi Azikiwe University & $\mathrm{h} 1$ & Federal University of Petroleum Resources Effurun \\
\hline $\mathrm{f}$ & University of Maiduguri & i1 & Bells University of Technology Otta \\
\hline $\mathrm{g}$ & Rivers State University of Science \& Technology & $\mathrm{j} 1$ & Federal Polytechnic Mubi \\
\hline $\mathrm{h}$ & Enugu State University of Science and Technology & $\mathrm{k} 1$ & University of Agriculture Abeokuta \\
\hline $\mathrm{i}$ & Obafemi Awolowo University & 11 & Landmark University \\
\hline $\mathrm{j}$ & Ahmadu Bello University & $\mathrm{m} 1$ & University of Jos \\
\hline $\mathrm{k}$ & Federal University of Technology Akure & $\mathrm{n} 1$ & University of Calabar \\
\hline 1 & Federal University Oye Ekiti Ekiti State & o1 & $\begin{array}{l}\text { Ekiti State University Ado Ekiti } \\
\text { (University of Ado Ekiti) }\end{array}$ \\
\hline $\mathrm{m}$ & University of Uyo & p1 & Imo State University Owerri \\
\hline $\mathrm{n}$ & Elizade University Ilara Mokin & $\mathrm{q} 1$ & $\begin{array}{l}\text { Cross River State University of Science \& Techno- } \\
\text { logy Calabar }\end{array}$ \\
\hline $\mathrm{O}$ & Akwa Ibom State University of Technology & $\mathrm{r} 1$ & Federal Polytechnic Bauchi \\
\hline $\mathrm{p}$ & University of Ibadan & s1 & Adeleke University Ede \\
\hline $\mathrm{q}$ & University of Nigeria & $\mathrm{t} 1$ & $\begin{array}{l}\text { Olabisi Onabanjo University (Ogun State Univer- } \\
\text { sity) }\end{array}$ \\
\hline $\mathrm{r}$ & Afe Babalola University Ado Ekiti & $\mathrm{u} 1$ & Osun State University \\
\hline $\mathrm{s}$ & Madonna University Nigeria & $\mathrm{v} 1$ & African University of Science \& Technology Abuja \\
\hline $\mathrm{t}$ & Bayero University Kano & w1 & Nigerian Defence Academy Kaduna \\
\hline $\mathrm{u}$ & Ladoke Akintola University of Technology & $\mathrm{x} 1$ & Polytechnic Ibadan \\
\hline $\mathrm{v}$ & Kaduna Polytechnic & $\mathrm{y} 1$ & Federal Polytechnic Ilaro \\
\hline $\mathrm{w}$ & Baze University Kuchigoro & $\mathrm{z} 1$ & Gregory University Uturu \\
\hline $\mathrm{x}$ & University of Benin & a11 & Kano University of Science and Technology Wudil \\
\hline $\mathrm{y}$ & Auchi Polytechnic & b11 & Western Delta University \\
\hline $\mathrm{z}$ & Yaba College of Technology & $\mathrm{c} 11$ & Lead City University Ibadan \\
\hline a1 & Ambrose Alli University Ekpoma & $\mathrm{d} 11$ & American University of Nigeria \\
\hline b1 & Igbinedion University Okada & $\mathrm{e} 11$ & Oduduwa University Ipetumodu Osun State \\
\hline $\mathrm{c} 1$ & Nigerian Turkish Nile University Abuja & $\mathrm{f} 11$ & Adekunle Ajasin University \\
\hline
\end{tabular}

3. ASSOCIATION E. S., 2016, Pumped Hydroelectric Storage, http://energystorage.org/energy-storage/tec hnologies/pumped-hydroelectric-storage.

4. CHARLES A., 2014, How is $100 \%$ renewable energy possible for Nigeria? http://geni.org/globalenergy/ research/renewable-energy-potential-of-nigeria/100 percent-renewable-energy-Nigeria.pdf.

5. CHIYEMBEKEZO S.K., CUTHBERT Z.K., TORBJORN K.N., 2012, Energy Potential of SmallScale Hydropower for Electricity Generation in SubSaharan Africa, in: International Scholarly Research Network.

6. DAI H., 2015, A literature review of stochastic programming and unit commitment, in: Journal of Power and Energy Engineering, 3(04), p. 206.

7. DAY R., WALKER G., SIMCOCK N., 2016, Conceptualising energy use and energy poverty using a capabilities framework, in: Energy Policy, 93, p. 255-264.

8. DEL RIO P., BURGUILLO M., 2008, Assessing the impact of renewable energy deployment on local sustainability: Towards a theoretical framework, in: Renewable and Sustainable Energy Reviews, 12(5), p. 1325-1344.

9. DIOHA M. O., EMODI N.V., MATHEW M., DIOHA E.C., 2018, Techno-economic feasibility of domestic solar water heating system in Nigeria, Paper presented at the 2018 International Conference on Power Energy, Environment and Intelligent Control (PEEIC).

10. EMODI N.V., BOO K.-J., 2015, Sustainable energy development in Nigeria: Current status and policy options, in: Renewable and Sustainable Energy Reviews, 51, p. 356-381,

DOI: 10.1016/j.rser.2015.06.016.

11. Energy Poverty, 2016, http://www.iea.org/topics/ energypoverty/.

12. Federal Government Energize Rural Communities with Small Hydros, 2016, Abuja.

13. ISOKEN G. IDEMUDIA D.B.N., 2016, Nigeria Power Sector: Opportunities and Challenges for Investment in 2016, in: Client Alert White Paper, p. 1-15.

14. JAYESH D.S., ARUN K.D., PATIL P.N., SHAILENDRA K.D., 2013, Small Pumped Storage Hydro Power Plant - A Feasibility Study for MIDC Dhule, Maharashtra, in: Global Journal of Researches in Engineering Electrical and Electronics Engineering, 13(12).

15. JOHN T.M., UCHEAGA E.G., BADEJO J.A., ATAYERO A.A., 2018, Is There a Link between Air Pollution and Economic Growth?, Paper presented at the Proceedings - 2017 International Conference on Computational Science and Computational Intelligence, CSCI 2017.

16. JOHN T.M., UCHEAGA E.G., OLOWO O.O., BADEJO J. A., ATAYERO A.A., 2017, Towards 
building smart energy systems in sub-Saharan Africa: A conceptual analytics of electric power consumption, Paper presented at the FTC 2016 Proceedings of Future Technologies Conference.

17. KARKEZI S., McDADE S., BOARDMAN B., KIMANI J., 2012, Energy, poverty, and development, in: Global Energy Assessment Toward a Sustainable Future, eds. Johansson C., Pathwardhan T.B., Nakicenovic N., GomezEcheverri L., Cambridge University Press, Cambridge, United Kingdom and New York.

18. LEVIN T., THOMAS V. M., 2016, Can developing countries leapfrog the centralized electrification paradigm?, in: Energy for Sustainable Development, 31, p. 97-107.

19. MANDELLI S., MEREU R., 2013, Distributed generation for access to electricity: 'Off-main-grid' systems from home-based to microgrid, in: Renewable energy for unleashing sustainable development, Springer, eds. Colombo E. Bologna S., Masera D., p. 75-97.

20. MANOHAR K., ADEYANJU A.A., 2009, Hydro Power Energy Resources in Nigeria, in: Journal of Engineering and Applied Sciences, 4(1), p. 68-73.

21. MAS'UD, A.A., VERNYUY W. A., MUHAMMAD-SUKKI A., MAS'UD F., MUNIR I.A., MD YUNUS N., 2015, An assessment of renewable energy readiness in Africa: Case study of Nigeria and Cameroon, in: Renewable and Sustainable Energy Reviews, 51, p. 775-784, DOI: 10.1016/j.rser.2015.06.045.

22. MOSS T., BAZILIAN M., 2018,Signalling, governance, and goals: Reorienting the United States Power Africa initiative, in: Energy Research \& Social Science, 39, p. 74-77.

23. MURENZI J. P., USTUN T.S., 2015,. The case for microgrids in electrifying Sub-Saharan Africa, Paper presented at the Renewable Energy Congress (IREC), 2015 6th International.

24. OKEWU E., 2017, Model-Driven Engineering and Creative Arts Approach to Designing Climate Change Response System for Rural Africa: A Case Study of Adum-Aiona Community in Nigeria, in: Problemy Ekorozwoju/ Problems Of Sustainable Development, 12(1), p. 101-116.

25. OKEWU E., MISRA S., FERNANDEZ S.L., AYENI F., MBARIKA V., DAMASEVICIUS R, 2019, Deep Neural Networks for Curbing Climate ChangeInduced Farmers-Herdsmen Clashes in a Sustainable Social Inclusion Initiative, in: Problemy Ekorozwoju/ Problems Of Sustainable Development, 14(2), p. 143155.

26. OKEWU E., MISRA S., FERNANDEZ S.L., MASKELIUNAS R., DAMASEVICIUS R, 2018, An e-environment system for socio-economic sustainability and national security, in: Problemy Ekorozwoju/ Problems Of Sustainable Development, 13(1), p. 121-132.

27. OKOYE O. C., BAKER D.K., 2015, Solar energy potentials in strategically located cities in Nigeria: Review, resource assessment and PV system design, in: Renewable and Sustainable Energy Reviews, 55, p. 550-566.

28. OLAYINKA S., OHUNAKIN M.S.A., OLANREWAJU M. OYEWOLA R.O.F., 2014, Solar energy application and development in Nigeria:
Drivers and barriers, in: Renewable and Sustainable Energy Reviews, 32, p. 294-301.

29. OSUEKE C., EZUGWU C., 2011, Study of Nigeria Energy resources and its consumption, in:. International Journal of Scientific \& Engineering Research, 2(12), p. 121-130.

30. OSUNMUYIWA O., KALFAGIANNI A., 2017, Transitions in unlikely places: Exploring the conditions for renewable energy adoption in Nigeria, in: Environmental Innovation and Societal Transitions, 22, p. 26-40, DOI: 10.1016/j.eist. 2016.07.002.

31. Power People Planet, 2015, Seizing Africa's Energy and Climate Opportunities, in: Africa Progress Report 2015, https://reliefweb.int/report/world/afric a-progress-report-2015-power-people-planet-seizing -africas-energy-and-climate.

32. RAINER Q., S. R., JACOBS D., BAYER B., El MOSTAFA E.J., WAWERU Y., MATSCHOSS Y, atschoss, 2016, The Future of Africa's Energy Supply: Potentials and Development Options for Renewable Energy, Potsdam.

33. RAWORTH K., 2012, A safe and just space for humanity: can we live within the doughnut, in: Oxfam Policy and Practice: Climate Change and Resilience, 8(1), p. 1-26.

34. Research Centres, 2007, http://www.energy.gov.ng/ index.php?option $=$ com_content $\&$ view $=$ article $\&$ id $=5$ 4.

35. SAMBO A., 2008, Matching electricity supply with demand in Nigeria, in: International Association of Energy Economics, 4, p. 32-36.

36. SEBITOSI A., OKOU R., 2010, Re-thinking the power transmission model for sub-Saharan Africa, in: Energy Policy, 38(3), p. 1448-1454.

37. SMALLEY R. E., 2005, Future global energy prosperity: the terawatt challenge, in: Mrs Bull, 30(6), p. 412-417.

38. SORENSEN B., 2012, A history of Energy. Northern Europe from the stone age to the present day. Earthscan, New York.

39. SZABO S., BODIS K., HULD T.,MONER-GIRONA M., 2013,Sustainable energy planning: Leapfrogging the energy poverty gap in Africa, in: Renewable and Sustainable Energy Reviews, 28, p. 500-509.

40. THOMAS C.T., OGUNGUNBIYI O., AKOREDE M.F., YAHAYA B., ALABI, K.O., OLUFEAGBA B.J., 2019, Evaluation of Failure and Repair of the Jebba and the Shiroro Hydroelectric Power Stations, in: Journal of Failure Analysis and Prevention, 19(2), p. 488-495, DOI: 0.1007/s11668-019-00624-y.

41. TORRES O., 2011, Life Cycle Assessment of a Pumped Storage Power Plant., in: NTNU open.

42. WORLD BANK Indicators, 2020, Population, Total, https://data.worldbank.org/indicator/SP.POP.TOTL.

43. XUE S., SONG J., WANG X., SHANG Z., SHENG C., LI C., LIU, J. 2020). A systematic comparison of biogas development and related policies between China and Europe and corresponding insights. Renewable and Sustainable Energy Reviews, 117, 109474.

44. ZAHND A., STAMBAUGH M., JACKSON D., GROSS T., HUGI C., STURDIVANT R., SHARMA S., 2018, Modular Pico-hydropower System for Remote Himalayan Villages, in: Transition Towards 100\% Renewable Energy, Springer, p. 491-499. 